\title{
Balkanologie
}

Balkanologie Revue d'études pluridisciplinaires

Vol. III, n 1 | 1999

Volume III Numéro 1

\section{The Conflict in former Yugoslavia as a « Fault Line} War»?

Testing the validity of Samuel Huntington's « Clash of Civilzation »

Florian Bieber

\section{OpenEdition}

\section{Journals}

Electronic version

URL: http://journals.openedition.org/balkanologie/283

DOI: 10.4000/balkanologie.283

ISSN: 1965-0582

\section{Publisher}

Association française d'études sur les Balkans (Afebalk)

Printed version

Date of publication: 1 July 1999

Number of pages: $33-48$

ISSN: 1279-7952

\section{Electronic reference}

Florian Bieber, « The Conflict in former Yugoslavia as a « Fault Line War »? », Balkanologie [Online], Vol. III, $n^{\circ} 1$ | 1999, Online since 03 June 2008, connection on 17 December 2020. URL : http:// journals.openedition.org/balkanologie/283 ; DOI : https://doi.org/10.4000/balkanologie.283

This text was automatically generated on 17 December 2020.

(c) Tous droits réservés 


\title{
The Conflict in former Yugoslavia as a « Fault Line War »?
}

\author{
Testing the validity of Samuel Huntington's « Clash of Civilzation »
}

Florian Bieber

\section{Introduction}

1 Samuel Huntington's article « The Clash of Civilizations? ", published in Foreign Affairs in Summer 1993, resulted in heated debates to an extent rarely seen in response to an article in academia ${ }^{1}$. Three years later the book with the same title, bar the question mark, appeared, followed by a renewal of the controversial debates. While his book as been meet mostly with criticism in the academic world, it managed to successfully enter mainstream political discourse like few other "scientific" theories. The appeal of Huntington's theory is the attempt to develop an all-encompassing theoretical construct, which aims at explaining not only the conflicts of the present and future, but also at describing the key features of the international political system. As far as it also touches upon inner-state conflicts, its implications reach beyond international relations. Huntington's theory is also the academic articulation of a number of more crude journalistic explanations for conflicts between the West and mainly the Islamic world, as well as in former Yugoslavia ${ }^{2}$.

2 At the center of Huntington's theory stands the concept of civilization. He describes conflicts between civilizations as the prime source of conflict after the end of the Cold War. Civilization describes the way of life of a group. Huntington thus places civilization above narrower terms such as nation or language. At the center of Huntington's concept of civilizations stands religion:«To a very large degree, the major civilizations in human history have been closely identified with the world's great religions ; and people who share ethnicity and language but differ in religion may slaughter each other, as happened in Lebanon, the former Yugoslavia, and the Subcontinent $»^{3}$. 
3 It lies beyond the scope of this paper to present a general analysis or critique of Huntington's clash of civilizations. The war in Bosnia and elsewhere in former Yugoslavia nevertheless can be seen as a good tool for the testing the validity of the theory and detecting mistakes. This is partly because he himself offers Bosnia as an example of one of his key concepts, "fault line" wars. Furthermore, the Bosnian war superficially seems to fit nicely into concepts developed by the political scientist at Harvard. This papers aims at highlighting the fundamental flaws in Huntington's theory in regards to Bosnia and former Yugoslavia. In particular it will point out how the author neglects nationalism as a driving force for conflict. Furthermore, just like civilizations, nationalism as a reason for conflict is neither monolithic nor could it be described as a simple cause and effect relationship. Instead nation, as well as civilization, might serve as a mobilizing ideology for conflict.

4 Finally one will have to highlight how dangerously close Huntington comes to being an apologist for ethnic cleansing, and how he presents a grossly distorted picture of Islam, especially in the case of Bosnia.

\section{False Fault Line Wars}

In the forefront of the analysis offered in Clash of Civilizations stand conflicts between the leading countries, so-called core countries, of each civilization. He nevertheless also devotes attention to the aforementioned fault line wars. These wars involve nations, people or other groups of different civilizational provenance. Although such wars can be carried out between countries, Huntington underlines the fact that such conflicts are more likely to occur inside states which bridge different civilizations (cleft states). These conflicts are characterized by longer duration and more violence than interstate warfare. The war in Bosnia is put into this category of civilizational conflicts by the author ${ }^{4}$. These wars are potentially more dangerous than other wars, according to the theory of the Clash of Civilizations, as they inevitably draw in the kinsmen of both opponents (see chapter on «Civilizational Brotherhood»). As with global civilizational conflicts, also these local wars mainly focus on the religious component of civilizations : "Some analysts downplay the significance of this [religious] factor. They point, for instance, to the shared ethnicity and language, past peaceful coexistence, and extensive intermarriage of Serbs and Muslims in Bosnia, and dismiss the religious factor with references to Freud's "narcissism of small differences". That judgement, however, is rooted in secular myopia $»^{5}$. The author rightfully mentions the fact that all inhabitants of Bosnia share the same language and the same ethnic origins. Nevertheless a war broke out which defined itself upon the differences between the inhabitants of this country. Thus Huntington seems to be correct when assuming that religion consequently has to be the main cause for conflict. The difference in religion during the course of the war has lead a division of the language, a division of the territory and the questioning of common ancestry, or as Radovan Karadžić compared Serbs and Croats with cats and dogs : "You can't keep a dog and a cat in a box together. Either they would always be quarreling and fighting or they would have to stop being what they are ${ }^{6}$. 


\section{The Absence of Nationalism}

6 The Clash of Civilizations makes in this context (as in the whole text) suspiciously little mention of nationalism. Huntington subsumes nationalism under the greater category of civilization and sees it as a more specific component of the larger concept. By completely ignoring nationalism as a cause of the war in Bosnia, Huntington seems oblivious to the development of nation states and nationalism in this region of Europe in the past 200 years. While at the beginning of the $19^{\text {th }}$ century the prime identifying characteristic of the different populations in Bosnia and the Balkans was religion, it has since been replaced by nationality. Nationalism and nations in general contain religious components, and more specifically in the case of Serbs, Croats and Muslims, the prime difference (besides a partially different historical development) was religion. Nevertheless, it would be false to claim religion to be the main dividing element between Croats, Muslims and Serbs. The difference between the three groups is the sense of belonging to three different nations. While it would lead beyond the scope of this paper to highlight the "ingredients" of nations and nationalism, it will suffice at this point to bear in mind that they constitute a highly complex mixture of perceived common historical experience, a development of common consciousness and the perception that the unifying elements outweigh the commonalties with other (usually neighboring) nations. Religion is an important component in such a differentiation from the other, especially in cases where other criteria, such as language or ethnic origins, are identical. In this light one has to bear in mind that while Serbian nationalism differs from Croatian nationalism primarily by religion and different perceived historical experience, the difference with Bulgarian or for that matter Macedonian nationalism is not based on religion, but on language. And, needless to mention, Serbia and Bulgaria have had numerous national conflicts in the past. To single out the recent war in Bosnia and Croatia as being a new phenomena and expression of civilizational conflict means ignoring the history of national conflicts in the region and ignores the proper context of the war?

\section{The Difference Between Perception and Reality}

7 The war in Bosnia is justified as a "fault line" war by the appropriation of religious grounds for conflict by the Croat, Serb and Muslim leaderships, and they have frequently described their opponents in such (mostly derogatory) terms ${ }^{8}$. While this component played an important role in the demonization of the opponent during the war, it was merely one element. Thus, reducing the stereotypes used during and before the war to merely religious or civilizational factors simplifies the broadness and multidimensionality of the supposed "otherness". Furthermore Huntington does not draw a clear line between the perception of civilizational difference and the real content of the presupposed opposition. Along these lines, if one where to take the rhetoric of most communist regimes during the cold war, conflicts (e.g. Vietnam) were usually the expression of class struggle, either internally or on the global scale of conflict between the socialist and capitalist countries. Despite this given explanation, few serious academics would maintain that these wars were truly such class struggles, even if perceived as such by one side. This failure to differentiate between the given and perceived reason for conflict in Bosnia (and other cases mentioned by Huntington as 
civilizational conflicts) gives rise to the objection made by Maria Todorova that Huntington's theory resembles a prescription rather than a prediction'.

\section{The Civilizational Brotherhood}

8 Samuel Huntington assumes that not only international relations but also internal conflicts will be shaped increasingly by confrontations between civilizations. Other explanations for such conflicts, such as economic factors, receive at best secondary attention of the author. He does not deny the possibility of intra-civilizational conflicts, but grants them less importance as they are less likely to lead to broader conflict: "Violence between and groups of different civilizations, however, carries with it the potential for escalation as other states and groups from these civilizations rally to the support of their "kin countries" »".

One of the dangers of civilizational conflicts according to Huntington is the involvement of "kin-countries" of the groups fighting the fault line wars. The involvement of "kin" leads in his view to a widening of the conflict and also brings the danger of tensions or even conflict between the larger civilizational groups. The allies of the conflicting parties in their civilization can also help restrain their warring kin and negotiate with the other civilizational group.

\section{National Interest Determines "Civilizational Alliances"}

10 In his critique of Huntington's article in Foreign Affairs Foud Ajami reminds the reader that states are still the central unit of international relations and their kin ties are only mobilized for their one usefulness : "Civilizations do not control states, states control civilizations. States avert their gaze from blood ties when they need to; they see brotherhood and faith and kin when it is in their interest to do so ${ }^{11}$. In this light one can analyse the supposed kin-relationship between Muslims, Serbs and Croats and their kins.

11 Huntington groups all Muslim countries together, even such different states as Libya, Turkey or Iran. While some might share the same anti-Western policy, it would be difficult to claim that Libya is a Islamist country, bearing in mind that its leader Ghaddafi seeks to promote Arab socialism and suppresses Islamists in his own country. Their support for Bosnia, if granted, was thus more driven by national interests than any civilizational affinity. Furthermore, the support of most Muslim countries was symbolic to the point of being limited to rhetoric expressions of sympathy with the Bosnian Muslims, and accusations addressed to the passivity of the "West". The only country granting military aid on a significant scale was Iran (with the tacit consent of the United States). Although Iran is a Muslim state, the difference between the Shia regime in Tehran and the secular Sunni Muslims of Bosnia is so obvious and stark that the primary intention even of Iran was more likely to be the expansion of its sphere of influence than the establishment of a Muslim state ${ }^{12}$. Turkey, the only country with close historical connections to Bosnia, limited its support mostly to the spectacular visit of prime minister Tansu Ciller to Sarajevo in 1993 and lobbying for Bosnia in international organizations. Huntington clearly overestimates the role of the Muslim world and is fooled by the rhetoric of many Muslim countries ${ }^{13}$. 

Muslim countries is the absence of a clear center (core state) of Islam, which would organize and discipline the Muslim world. Besides the dubious quality of such a dominant power, it would also mean that only a Muslim core country could assume a supporting role for the Muslims of Bosnia, which would not only be divisive for Bosnia, but also utterly inadequate for the Muslims of Bosnia, who have sought and maintained cultural ties with Europe and not with the Muslim world for an extended period of time ${ }^{14}$.

13 German, Austria and the Vatican are then named as the supporters of the Slovenian and Croatian quest for independence, while the Orthodox civilization supposedly supported Serbia ${ }^{15}$. While Germany and Austria did support Croatia and Slovenia during the early stages of the war (later to be largely replaced by the United States), one could ask why the equally Catholic and Western country France (or Great Britain for that matter) had little inclination to support the independence of either republic. Furthermore, among Orthodox countries there was no unified support for Serbia. Relations with Macedonia remained tense, and Romania did not engage in any substantial support for its "kin". The "notorious" Greek and Russian support, although voiced by supporters and opponents with great vigor, remained rather limited. In key matters, such as sanctions, both supported the general Western position ${ }^{16}$. Other noncivilizational consideration weighed much more. Their own minorities, and their real or possible quest for secession, limited the support for independence among some countries (e.g. France), while the support of others is due to economic interest, large diaspora groups or historical ties ${ }^{17}$.

14 As much as countries determine civilizations, the state plays great influence in shaping the loyalties of its population. These loyalties were defined primarily along national lines, not only in former Yugoslavia. In some cases, as in Bosnia, national identity overlaps with religion. Nevertheless, a Bosnian Muslim will primarily identify himself as a member of the Bosnian Muslim Nation. This identity defines itself not so much in adherence to a transnational umma, but rather as a means of separating oneself from Croat or Serb national identity ${ }^{18}$.

\section{The Similarities Across Civilizational Fault Lines}

15 These observations lead to the more general question of whether it is permissible to divide the nations of Bosnia into different civilizations and to describe the conflict as a fault line war. All three nations of Bosnia have been part of the same historical, cultural and geographical experience of the Balkans. Despite the linguistic and religious diversity of the region, it can be considered as a viable area ${ }^{19}$. The key components which Huntington attributes to Western civilization ; the classical heritage, Catholicism and Protestantism, European languages, the separation of state and church, rule of law, pluralism, individualism and representative institutions have been mostly as much or as little part of the formation of all of the national groups of Bosnia ${ }^{20}$. The Catholic, western, Croats in Bosnia have not been exposed to substantially more of these elements than the Islamic Bosnian Muslims or the Orthodox Serbs. They share the same history of the past centuries, although not necessarily the perception of history ${ }^{21}$.

The usage of the term civilization in this context is thus misleading. Civilizations are so complex that hardly any direct empirical relationships can be drawn. Essentially

Balkanologie, Vol. III, nº 1 | 1999 
Huntington's theory in the case of Bosnia seems to be rather a "Clash of Religions" than a civilizational confrontation ${ }^{22}$. The dangers of the religious analysis of Huntington shall be seen subsequently in the evaluation of his portrayal of Islam.

\section{The Image of Islam}

17 Particularly striking in the Clash of Civilizations is the attitude towards Islam and Muslims. In his analysis of the main sources of conflict in these clashes he singles out the Islamic civilization as the greatest destabilizer. The key term he uses in his article for Foreign Affairs in 1993 (and reiterates in his book) are the "bloody frontiers" of Islam, which he supplements by the equally bloody Binnenland of Islam ${ }^{23}$. According to him the biggest problem of Islam is the West, and for the West it is Islam, « a different civilization whose people are convinced of the superiority of their culture and are obsessed with the inferiority of their power ${ }^{24}$. Not only is Clash of Civilizations riddled with sweeping generalizations about Muslims and Islam, his overly enthusiastic usage of these leads to many factual misconceptions.

18 Frequently he attributes the label Muslim to societies which could hardly be described as such. Huntington, for example, frequently refers to the "Albanian Muslim" population in the context of Kosovo and Albania proper, where the equation of Muslims and Albanians is hardlly permissible. The majority of the Albanians in Kosovo are Muslim, but this does not hold true for the whole Albanian population and does not take into account the thoroughly secularized Albanian society in Kosovo ${ }^{25}$.

In the Clash of Civilizations stereotypes of Muslims are common place. Huntington claims, for example, that Islamism transformed «Bosnia from the Switzerland of the Balkans to the Iran of the Balkans ${ }^{26}$. It seems difficult to claim that Bosnia was the Switzerland of the Balkans, but even more demagogic to claim a parallel with Iran. The usage of "Iran" attempts to evoke the negative images the reader has of that country, without properly dissecting them.

In his conclusions he criticizes American policy towards the Balkans, and arrives at the position that «[p]ursuing the chimera of a multi-civilizational country, the Clinton administration denied self-determination to the Serbian and Croatian minorities and helped to bring into being a Balkan one-party Islamist partner of Iran $»^{27}$. It does not require profound knowledge of the course of the war and the reasons for its outbreak to spot the clear anti-Islamic bias ${ }^{28}$.

21 The two central components of Huntington's view of Islam, in particular with regard to former Yugoslavia, deserve further analysis: the demography of the Muslim population, where he distorts the real demographic facts in favor of his theory, and the supposed Islamic "fundamentalism" in Bosnia.

\section{Demography of Muslims}

22 When Huntington elaborates his thesis of the "bloody borders of Islam" he seeks an explanation (among other factors) in demography. The fundamental point made is the that the higher birth rate among Muslims has laid the foundations for conflict. This "demographic explosion" created a large population under 30 years of age, which was more ready than old generations to violently enforce their demands. This increase in 
Muslim population also, according to Huntington, created rightful fears of Muslim dominance among their non-Muslim neighbors. With respect to the war in Yugoslavia, he names the Albanians of Kosovo and the Muslims of Bosnia as examples of such a development.

With regard to Kosovo, he only mentions the drop of Serb population between 1961 and 1991 from $24 \%$ to $10 \%$, and the parallel rise of the Albanian population from $67 \%$ to approximately $90 \%{ }^{29}$. He fails to mention that the relationship between Serbs and Albanians had remained relatively stable between 1948 and 1961 and only then clearly changed. The high birth rate of Albanians, although a fact, was not the only reason for the increasing discrepancy. Between the two censuses in 1971 and 1981 the birth rate among Albanians was double of the Serbs in the Province, which obviously accounts for some of the higher proportion of the Albanian population. The key nevertheless is the emigration of Serbs from the province, which cancelled out the positive growth of the Serbs $^{30}$. The explanation given in Clash of Civilizations attributes this to the Albanian growth in population, discrimination and persecution against Serbs. The author in no way attempts to provide evidence for these claims, which were under much dispute in the 1980s. Obviously a great increase of the emigration rate of Serbs coincides with the increase of autonomy for Kosovo granted through the constitutional amendments of 1971 and the subsequent new constitution of 1974. The consequence of this was a shift away from Serb predominance over the region, to an increased Albanian participation. Although this also led to instances of discrimination, it would be to simplistic to overestimate this factor. A study carried out by the Serbian Academy of Arts and Sciences in 1985-1986 has examined the emigration of Serbs (and Montenegrins) from Kosovo. Of the emigrants questioned $67,2 \%$ of the respondents gave reasons largely unconnected to Albanian "persecution", such as general uncertainty, inability to find a job, social climate and their children. These factors ring true for nearly all underdeveloped regions, including Kosovo. National discrimination and similar reasons account for less than a third of the reasons given in this study ${ }^{31}$. Thus even a study sympathetic to the arguments of Huntington cannot verify his claim.

With regard to Bosnia, Huntington's explanation of the increase in Muslim population is even less acceptable as a reason. He points out the increase in the Muslim population between 1961 and 1991, from 26 to $44 \%$ of the population, during which period the Serb population dropped to 31 from $43 \%^{32}$. Such a simple comparison of figures is completely impermissable in relation to the Muslim population of Bosnia. As their status changed considerably between the end of the world war and the 1980s, each census carried different implications. In the 1948 Muslims could declare themselves only as Muslim Serbs, Croats or "nationally undecided" Muslims. In 1953 not even this option was available, while in 1961 the option to describe themselves as "ethnic Muslims" was introduced. Only from 1971 onwards did Muslims in Yugoslavia have the option to declare themselves as "Muslim in the national sense". This development coincided with a significant change in the relationship between the state and the Muslims. Only after the fall of Ranković, and the end of domination by the centralist faction in the League of Communists, was Muslim identity encouraged and fostered by the state. Due to the still unclear status of Muslims in 1961, many opted to declare themselves as "Yugoslavs". $87 \%$ of all "Yugoslavs" lived in Bosnia, and $84 \%$ of those were Muslims. Taking these factors into consideration together, the increase between 1961 and 1991 in the Muslims population was only from approximately 33 to $44 \%$. In 
absolute numbers the Muslim population increased in these three decades by approximately 800000 , while the number of Serbs stagnated and the Croat population grew only slightly ${ }^{33}$. While this increase is still noteworthy, it is by no means as extreme as Huntington presupposes, and cannot justify his statement: "ethnic expansion by one group led to ethnic killing by the other $»^{34}$.

The key factor in Bosnia which Huntington fails to see is not the demographic increase of the Muslim population, but the increased politicization of the Muslims. This increased political influence, a consequence of the promotion of Muslims in the 1960s to counterbalance the Serb-Croat antagonisms, made other nations worry about their predominance.

Huntington ends his chapter on the demographic development with the elaboration of four proposed reasons for the higher likelihood of conflict involving Muslims: militarism ; the perception of being a victim among Muslims; the demographic factor and the incapability of Muslims and their religion to "digest" non-Muslim population. All these arguments sound scaringly like the arguments put forward by Serb nationalist extremists during the war in Bosnia. The great capability of the secular Muslims of Bosnia to coexist with non-Muslim populations, the absence of militarism, even after the outbreak of the war and the true victim status of Muslims in Bosnia are lightly ignored by the author ${ }^{35}$. Along these lines the "Minister of Information" Velibor Ostojic of the "Repulika Srpska" claimed : "Islam is rising everywhere. Christian Lebanon and Cyprus have fallen already. Furthermore Muslims reproduce very quickly ${ }^{36}$.

\section{Muslim Fundamentalism}

While Huntington observes a general turning away from multinational life in Bosnia towards extremism, he sees this development among Muslims as being "even more marked" than among Serbs and Croats. The fact that Izetbegović is a "devout Muslim" contributes little to justifying this claim, just as his brief quotes from his Islamic Declaration lacks any contextualization and explanation. This Declaration clearly points out that no Islamic state should be established in a state which is not in a majority populated by Muslims (thus Bosnia is excluded). Furthermore, it is rather a critique of corrupt regimes in Muslim states and of their policies, than a call to establish Islamic states. (In fact, neither Bosnia nor Yugoslavia are mentioned in the declaration).

What is more, Huntington's interpretation of the SDA's electoral victory as a sign of Islamism cannot be upheld. At the time the SDA encompassed a multitude of factions in the spectrum of Muslim intellectuals. It is necessary to point out that Fikret Abdić, a buisnessman and member of the former communist nomenklatura, received more votes for the presidency in 1990 than did Alija Izetbegović, which clearly demonstrates the limited support among Bosnia's "Muslims" for a religious policy.

While it is correct that Serbs and Croats were increasingly excluded from the institutions in government-controlled areas, and an attempt began to create a separate Bosnian language, ignoring the circumstances in which these developments took place makes Huntington an apologist for the crimes committed by Serb and Croat armies. The complete exclusion, persecution and murder of Muslims preceded any of the actions mentioned by Huntington. Also, the division of the Serbo-Croatian language into Serbian and Croatian took place before the establishment of a Bosnian language. The actions taken by the government of Bosnia thus were a reaction to much harsher 
measures already implemented by the Serb and Croat statelets in Bosnia. The fact that Serbs and Croats enjoyed far more protection than Muslims in their other parts of Bosnia shows that Muslim nationalism was far less extremist and largely a reaction to its Serb and Croatian counterparts ${ }^{37}$. The radicalization of Muslims during the war should not be seen as unusual, given the circumstances of Croat/Serb control of up to 80 percent of Bosnian territory, and the more extreme policies pursued by some Muslim leaders can not or should not be reduced to the nature of Islam, but rather to the state of war.

In his argument, however, Huntington follows the line of many Serbian apologists who attempt at justifying the campaign launched by the Bosnian Serb army against Bosnia in April 1992 as a reaction to Islamist policies ${ }^{38}$.

\section{Civilization and Religion as a mean of political mobilization}

As has been shown by the above analysis, religion and civilization do not constitute the kind of source of conflict, which Huntington attributes to them. Both rather serve as instruments of nationalist ideology and its proponents in achieving their goals ${ }^{39}$. Within a group, internal differences and conflicts can be pasted over by religious or national mobilization. This process of national identity formation is twofold. One side it requires an inclusive definition of its members. Secondly, it necessitates an exclusion, creating a separation from other, usually neighbouring groups. This self-definition, however, is subject to change according the internal needs of the group and its external balance of power in relationship to others :

We should also be aware of the temporal dimension through which the complex process of reconstituting traditions and activating collective memories occurs. And finally, we need to think about collective identities in their spatial dimension : in the present context we might think of nations and ethnies that aspire to have states or forms of autonomous rule in an area of territorial concentration. ${ }^{40}$

The national groups in Bosnia, as elsewhere, do not constitute monolithic units, they are rather divided into a multitude of social and economic differences. Elites can cover up these differences through manipulating the subjective adherence of the group to nationalism, or any other powerful ideology, and thereby enhance its influence over this community. National and religious aims help to legitimize its proponents, and removes them from conventional accountability for their policies. Every opposition to the leaders can be interpreted as treacherous.

Religious and national factors also serve to delimit oneself from others. This separation is only feasible, as long as the other group is clearly identified and classified as "alien" ${ }^{41}$. In terms of distancing oneself as far as possible from neighbours, religious justifications can often be more helpful than national ones. As most religions encompass a larger area than nations, they help create a greater distance between neighbours. From the national position Muslims can only be presented as "alien" to a limited degree. When national rhetoric is supplemented by religious arguments, however, this enables the nationalists to represent the Muslims as being completely alien and oriental. While national arguments can at best mentally displace Muslims to Turkey, religious arguments can alienate them to places as far away as Iran or the Arab world ${ }^{42}$. From here it is only a small step to accuse the other group as being an "agent" 
of this foreign civilization. Along these lines Croats were represented as a "Trojan horse" of the Vatican or the Muslims of Iran. These supposed ties are similar to Huntington's supposed ties with the so-called "kin-countries" of the local conflicting parties. Although such contacts existed at times, their perception by other groups has been of greater importance. The intensity of the conflict in Bosnia was largely caused by perceptions of "otherness" and these constructed or real alliances greatly helped to underline these supposed differences ${ }^{43}$.

The theory of the Clash of Civilizations also neglects the mutual enhancement of national identities through conflict. At the origins of this vicious circle national identities have frequently been consciously or unconsciously mobilized by politicians or other members of the elites for their own political or material benefit. Huntington and other authors have thus confused civilizational fault lines with nationally constructed differences, which are subject to change, according to the historical situation :

Balkan strife has re-emerged not just because of cultural differences, but because crises of modernization which have not run their course re-emerged with the collapse of communism. Everywhere, the arrival of modernity creates stresses for social and political organization : a modern state must be built amidst the remnants of a traditional society ; exposure to market forces imposes the pain of adjustment; old and new élites vie for leadership of politically activated masses ${ }^{44}$.

Warren Zimmermann, the last US ambassador to Yugoslavia, underlines the conscious manipulation of historical facts by politicians in Serbia, Croatia and Bosnia. For their own legitimization current conflicts are projected into the past and thus appear "ancient" and inevitable. In reality most current conflicts in former Yugoslavia have their roots in the $19^{\text {th }}$ century and in most cases lead to violence only during World War II, while some of the most bloody fighting before took place between the Orthodox "kins"; Serbia and Bulgaria during the second Balkan War. At the same time other regions of the world suffered from no less intense wars (e.g. the frequently forgotten American Civil War), without this justifying a source of conflict today or proving the impossibility of life together ${ }^{45}$. The way in which Huntington presents the conflict in former Yugoslavia could be described as an extension of Oritentalist discourse, as outlined by Edward Said or, more narrowly, as segment of the Balkanism, which Maria Todorova describes :

In the face of persistent hegemonic discourse from the West, continously disparaging about the Balkans, which sends out messages about the politization of essantialized cultural differences (like the Huntington debate), it is hardly realistic to expect the Balkans to create a liberal, tolerant, all-embracing identity celebrating ambiguity and a negation of essentialism ${ }^{46}$.

While the theory of Huntington seems appealing at first sight, and after a superficial glance at the papers' headlines seems the appropriate explanation for the war in former Yugoslavia, it fails on several levels. Not only is the empirical and anecdotal evidence he provides shaky and riddled with mistakes, but also his approach is very ahistorical and lacks key elements for the understanding of the region. The absence of nationalism in Huntington's theory is hard to justify, especially as he provides no justification or evidence for a possible switch from national to civilizational loyalties ${ }^{47}$. Finally, he fails to make a clear differentiation between the perception of differences and their reality. While it is easy to dismiss the theory of Huntington, one should not overestimate it enormous influence beyond academia and see it as a reflection of a multitude of far less refined opinions not uncommon in many levels of Western (and other) societies. The Clash of Civilizations is also clear evidence of the dangers of any 
attempt to create a global, all-encompassing theory, whether of international, conflicts or internal strife.

\section{NOTES}

1. Huntington (Samuel P.), «The Clash of Civilizations? », Foreign Affairs, 72 (3), Summer 1993. For the reactions see « Responses to Samuel Huntington's "The Clash of Civilizations? », Foreign Affairs, 72 (4), September/October 1993.

2. For some of the analyses of Huntington see «Cultural Explainations. The man in the Bagdad café », The Economist, 09/11/96 ; Heine (Peter), Konflik der Kulturen oder Feindbild Islam, Freiburg / Basel / Wien : Herder, 1996; Tibi (Bassam), Krieg der Zivilisationen. Politik und Religion zwischen Vernunft und Fundamentalismus, Hamburg, 1995; Axt (Heinz-Jürgen), « Kampf der Kulturen? Europa nach Ende des Ost-West Konflikts », Europäische Rundschau, 22 (4), winter 1994.

3. Huntington (Samuel P.), The Clash of Civilizations and the Remaking of World Order, New York: Simon \& Schuster, 1996, p. 42.

4. Ibid., pp. 266-267.

5. Ibid., p. 254.

6. Quoted from Zimmermann (Warren), «Last Chance for Bosnia? ", The New York Review of Books, 18 (20), 19/12/96.

7. See Walt (Stephen M.), «Building up New Bogeymen », Foreign Policy, (1), March 1997. Walt particularly points in his critique to the Huntington's inability to justify the swift from national to civilizational conflicts.

8. While this is true for the case of Bosnia, interestingly, most anti-Albanian rhetoric in Serbian media does not underline the Muslim element, but rather makes use of other derogatory words, such as "Shiptars", see Teokarević (Jovan), «Balkan Nations and Internal Minorities in the FR Yugoslav Press ", Balkan Neighbours Newsletter, 5, 1997. On this issue see Bakić-Hayden (Milica), «Nesting Orientalisms : The Case of Former Yugoslavia», Slavic Review, 54 (4), Winter 1995. She describes the way in which religious and other terminology was used for nationalist purposes.

9. Todorova (Maria), Imagining the Balkans, New York / Oxford : Oxford University Press, 1997, p. 131.

10. Huntington (Samuel P.), op.cit., p. 28.

11. Ajami (Foud), « The Summoning », Foreign Affairs, 72 (4), September/October 1993, p. 9.

12. Although Iran support Islamist movements, such support has usually been conditioned by national interest as well. See Rasoul (Fadil), Kultureller Dialog und Gewalt, Aufsätze zu Ethnizität, Religion und Staat im Orient, Vienna, 1991, pp. 105-110.

13. Huntington contradicts himslef here, as he uses Turkey's support for Bosnia as an example of Islamic kinship, while elsewhere criticizes Turkey for its secular policies and its refusal to play its role in the Islamic civilization. On the Turkish support for Bosnia, see Axt (Heinz-Jürgen), « The "Islamic Arc" from the Balkans to Central Asia", Balkanländer im Europa der Gegenwart, Thessaloniki / München: Institut für Balkan-Studien \& Südosteuropa-Gesellschaft, 1994 [Symposium 22-23/05/92]. On the positions of other Muslim countries, see Sahara (Tetsuya), "The Islamic World and the Bosnian Crisis», Current History, 93 (586), November 1994, and Erzeren (Ömer), «"Kreuzzug gegen den Islam”, Die Reaktion der Türkei und der islamischen 
Welt auf den Krieg in Bosnien », in Rathfelder (Erich), ed., Krieg auf dem Balkan. Die europäische Verantwortung, Reinbeck : Rowohlt, 1992.

14. Huntington (Samuel P.), op.cit., pp. 264-265.

15. Ibid., pp. 281-291.

16. Kandelj (Pavel), "Huntington's "Clash of Civilisations", Russia and the Balkans », Balkan Forum, 4 (1), March 1996.

17. For the postion of the European Powers and the United States see Zametica (John), The Yugoslav Conflict, London: Adelphi Paper (270), 1992, pp. 46-65 and Woodward (Susan L.), "International Aspects of the Wars in Former Yugoslavia », in Udovicki (Jasminka), Ridgeway (James), eds., Burn This House: The Making and Unmaking of Yugoslavia, Durham / London: Duke University Press, 1997. The divergent strategic and non-civilizational interests are well presented in Vukadinović (Radovan), "The Disintegration of Yugoslavia : Lessons to be Learnt ", in Clesse (Armand), Kortunov (Andrei), eds., The Political and Strategic Implications of the State Crises in Central and Eastern Europe, Luxembourg : IEIS, 1993.

18. In 1993, the "Muslims" renamed themselves into "Bosniacs". This can be seen as an attempt to separate national from religious identity, see Babuna (Aydin), Die Elite und die nationale Entwicklung der bosnischen Muslime. Mit besonderer Berücksichtigung der österreichisch-ungarischen Periode, unpublished dissertation, Vienna, 1994.

19. Todorova (Maria), op.cit., p. 11.

20. Huntington defines Western civilization in contradictory terms. One side as a concept based on Catholicism and Protestantism, one the other side thoroughly secular, see Huntington (Samuel P.), op.cit., pp. 56-78.

21. Beyond doubt did the belonging to different empires, Ottoman and Habsburg, influence the national movements of Croats and Serbs as whole. On the term Southeastern Europe, its commonlities and differences, see Kaser (Karl), Südosteuropäische Geschichte und Geschichtswissenschaft, Wien / Köln : Böhlau, 1990, pp. 103-114.

22. In this context The Economist writes : «If you take an extreme position, you could argue (...) that cultures are so complicated that they can never be used to explain behaviour accurately. Even if you do not go that far, the lesson must be that the same culture embraces such conflicting features that it can produce wholly different effects at different times» («Cultural Explainations ", The Economist, 09/11/96).

23. Speech given by Samuel Huntington at the Österreichische Industriellenverband (Vienna, 12 December, 1996).

24. Huntington (Samuel P.), op.cit., p. 217.

25. Idem, p. 260. It has been estimated, due to the absence of a religious census in Communist Albania that $70 \%$ of the population were Muslim at the end of World War II, about $20 \%$ Orthodox, and $10 \%$ Roman Catholic. Accordingly the Albanian intellectual of Roman-Catholic origin, Vaso Pashko, coined the phrase "the religion of the Albanians is Albanianism». See Kolsti (John), «Albanianism : From the Humanists to Hoxha », in Klein (George), Reban (Milan J.), eds., The Politics of Ethnicity in Eastern Europe, New York / Boulder : Columbia University Press / East European Monographs, 1981. On this matter see also Liolin (Arthur E.), « The Nature of Faith in Albania : Towards the 21 ${ }^{\text {st }}$ Century ", Eastern European Quarterly, 31 (2), June 1997.

26. Huntington (Samuel P.), op.cit., p. 270.

27. Ibid., p. 309.

28. All these anti-Islamic views oddly contradict his demand for Turkey to give up its Western orientation : " Turkey, in effect, could "do a South Africa" : abandoning secularism as alien to its being as South Africa abandoned Apartheid and thereby changing itself from a pariah state in its civilization to the leading state of that civilization ", Huntington (Samuel P.), op.cit., p. 179.

29. Ibid., p. 260. 
30. As it was written at a period of political exploitation of the issue, it is hardly an objective source, but it certainly cannot be attacked for its sympathy to the Albanian population : Petrović (Ruža), Blagojević (Marina), The Migration of Serbs and Montenegrins from Kosovo and Metohija. Results of the Survey Conducted in 1985-1996, Belgrade: Serbian Academy of Sciences and Art, Department of Social Sciences [Demographic Studies (3)], 1992, pp. 77-82.

31. Ibid., p. 183.

32. Huntington (Samuel P.), op.cit., p. 261.

33. Friedman (Francine), The Bosnian Muslims : Denial of a Nation, Boulder : Westview, 1996, p. 155.

34. Huntington (Samuel P.), op.cit., p. 261.

35. Ibid., p. 265.

36. Quoted from Erzeren (Ömer), art.cit., p. 122.

37. Huntington (Samuel P.), op.cit., pp. 269-270.

38. This point is also what Pierre Hassner in his critique accuses Huntington most of, see Hassner (Pierre), « Moralisch Fragwürdig, politisch Gefährlich : Zu Huntington's Werk "Kampf der Kulturen” », Europäische Rundschau, 25 (3), summer 1997, p. 105. See, for example, Dreschner (Karlheinz), Petrović (Milan), Weltkrieg der Religionen. Der ewige Kreuzug auf dem Balkan, Stuttgart / Wien, 1995 ; ćosić (Dobrica), L'Effondrement de la Yougoslavie. Positions d'un Résistant, Lausanne : L'Age d'Homme, 1994, pp. 75-79 ; Bodansky (Yossef), Forrest (Vaughn S.), «Iran's European springboard?", Task force on terrorism \& unconventional warfare, Washington: House Republican Research Committee, 01/09/92.

39. Bakić-Hayden (Milica), art.cit., pp. 930-931.

40. Schlesinger (Philip), « Media, the political order and national identity », Media, Culture and Society, 13, 1991, p. 300.

41. Allcock (John), « Rhetorics of Nationalism in Yugoslav Politics », in Allcock (John B.), Horton (John J.), Milivojević (Marko), eds., Yugoslavia in Transition: Choices and Constraints. Essays in Honour of Fred Singleton, Providence / Oxford, 1992 ; Ramet (Sabrina Petra), « The Roots of Discord and the Language of War ", in Ramet (Sabrina Petra), Adamovich (Ljubiša S.), eds., Beyond Yugoslavia. Politics, Economic and Culture in a Shattered Community, Boulder : Westview Press, 1995.

42. As Bakić-Hayden points out, part of the stereotypes against Bosnian Muslims from the Serbian side is the "betrayal" symptome which accuses them to betray their Slav (implied Serb) identity because of their conversion to Islam. See Bakić-Hayden (Milica), art.cit., p. 927.

43. The perception of "otherness" frequently expresses itself in conspiration theories, linking the enemy to a larger network, aggrandizing the threat, see Knežević (Anto), An Analysis of Serbian Propaganda, Zagreb, 1992; Čolović (Ivan), "Die Erneuerung des Vergangenen», in Stefanov (Nenad), Werz (Michael), eds., Bosnien und Europa: Die Ethnisierung der Gesellschaft, Frankfurt : Fischer, 1994.

44. Snyder (Jack), «Potential European Crises in Historical Perspective : Intervention versus Localization ", in Clesse (Armand), Rotfeld (Adam Daniel), eds., Sources and Areas of Future Possible Crises in Europe, Luxembourg : IEIS, 1995, p. 5.

45. Zimmermann (Warren), art.cit., pp. 10, 12.

46. Todorova (Maria), op.cit., p. 59.

47. Walt (Stephen M.), art.cit. 


\section{ABSTRACTS}

The case of "former Yugoslavia" serves as a tool to test the validity of Huntington's theory. The author's aim is to highlight the fundamental flaws in his theory in regards to Bosnia and "former Yugoslavia", in particular by pointing out Huntington's neglect of nationalism as a driving force for conflict and his distorted picture of islam (especially in the case of Bosnia). 